\title{
Allergic Reactions in Orthodontic Patients: A Review
}

\author{
Reacciones Alérgicas en Pacientes de Ortodoncia: Una Revisión
}

\author{
Layla Beatriz Barroso de Alencar; Samara Crislâny Araújo de Sousa; Ismael Lima Silva; \\ Vitória Freitas de Araújo; Elaine Bezerra de Oliveira; Davson Tadeu Almeida Fonseca Filho; \\ Maria Carolina Bandeira Macena \& Fátima Roneiva Alves Fonseca
}

\begin{abstract}
ALENCAR, L. B. B.; SOUSA, S. C. A.; SILVA, I. L.; ARAÚJO, V. F.; OLIVEIRA, E. B.; FONSECA FILHO, D. T. A.; MACENA, M. C. B. \& FONSECA, F. R. A. Allergic reactions in orthodontic patients: A review. Int. J. Odontostomat., 15(1):132136, 2021.

ABSTRACT: Allergic reactions are host immune responses to endogenous or exogenous antigens, which can result in local and systemic problems. Among the main allergens are the dental materials used in orthodontics, which faces some challenges with regard to biocompatibility with oral tissues. This study aimed to analyze in the literature which materials used in orthodontics are related to the appearance of oral and perioral allergic reactions, as well as to investigate the most prevalent manifestations.An integrative review was carried out with articles published between 2010 and 2020 on the PubMed, Embase, and ScienceDirect on-line database. For this, MeSH descriptors and synonyms were used following two semantic fields: "Hypersensitivity" in association with "Orthodontic Appliances", the selection of studies counted with the stages of identification, screening, eligibility and inclusion. Randomized clinical trials, cross-sectional or cohort clinical trials; Patients with allergic reactions affecting the oral or perioral region due to contact with orthodontic material, were included in the review.From a total of 549 articles only 04 were selected for the study. In accordance with what has been analyzed in the evidence of these studies, periodontal changes such as gingival inflammation as well as erythema, edema, papules and blisters were the main reactions described. Furthermore, in all articles there was an association with nickel and in only one with chromium. It is possible to infer that inflammatory lesions are frequent manifestations on the use of nickel in orthodontic patients.
\end{abstract}

KEY WORDS: allergic reaction; orthodontics; biomedical and dental materials.

\section{INTRODUCTION}

The reactions of hypersensitivity or allergies, are excessive immune system responses to a particular endogenous or exogenous antigen/allergen and which may, according to the intensity of the response, present systemic or local consequences (Kumar, 2010). This fact occurs through subsequent exposure to the antigen preceded by a primary contact. Thus, the allergen releases inflammatory mediators by binding to $\mathrm{lgE}$ on the surface of mast cells, in order to cause smooth muscle contraction, vasodilation, increased glandular activity and capillary permeability (Gaujac et al., 2009). Epidemiologically, $10 \%$ to $15 \%$ of the world population has sometype of allergic reaction (Andrade et al., 2004).

In systemic reactions, bronchospasm, vasomotor collapse, laryngealedema, and hypotension areprevalent manifestations, evidencing the need for greater attention in diagnosis and treatment, in view of the imminent risk of death. In addition, the individual's local responses involve papules, in addition to pruritus, urticaria and erythema, which may be associated with contact dermatitis (Gaujac et al.). In this scenario, the adhesive test is the standard procedure for the diagnosis of this manifestation arising from materials with high allergen potential, as well as being a necessary step to establish the recognition of the same (Chakravarthi et al., 2012).

In this sense, it is known that many substances can trigger harmful effects. Thus, in the dental clinic, a wide variety of materials are handled, which come into contact with oral tissues and organic fluids, which can cause adverse reactions in the oral cavity (Freire et al., 2012). This is due to the fact that the interaction that occurs at 
the material/tissue interface is dynamic and depends on a series of factors such as the location to be implanted the biomaterial, the material properties and the biological response of the host (Anusavice, 2005).

Thus, among the dental specialties, orthodontics faces some challenges in relation to the biocompatibility of oral tissues with the materials used in orthodontic treatment, which are composed of metals such as nickel, cobalt and chromium, in addition to other compounds present in acrylic resins such as methyl-methacrylate monomers (Chakravarthi et al.). Therefore, the objective of this work is to learn from the literature which materials used in orthodontics are related to the appearance of oral and perioral allergic reactions, as well as to investigate the most prevalent manifestations.

\section{MATERIAL AND METHOD}

Search strategy: In March 2020, an integrative search was conducted for data published from 2010 to 2020 in the online databases PubMed (National Library of Medicine), Embase and ScienceDirect. For this, MeSH descriptors and synonyms were used, organized in Boolean logic following two semantic fields: "Hypersensitivity" in association with "Orthodontic Appliances". Table I shows the research strategies used.
Select of studies. The selection of studies involved the following steps: identification, screening, eligibility and inclusion. Two independent researchers $(K=1.00$, obtained with $42 \%$ of the articles from the eligibility stage), participated in all phases and when a title was not agreed to choose, a third researcher decided.

For the selection of articles, no language limitation was imposed, in addition other inclusion criteria were: (1) article published in the last 10 years, (2) randomized clinical trials, cross-sectional or cohort studies, (3) patients with allergic reactions that affect tissues of the oral cavity or perioral region arising from contact with orthodontic material.

In the first approach, potentially eligible articles were chosen from reading the title and abstract using the website "Rayyan QCRI for Systematic Reviews". Subsequently, articles common to the two databases were screened and excluded. For eligibility, the full articles were read considering the proposed criteria.

Data extraction. From the articles included in this review, some information was removed, such as authors and year of publication; kind of study; sample size; area (s) affected by an allergic reaction and allergy-related orthodontic material. Such data were grouped and organized in a descriptive manner in this article.All selected titles were stored and managed in the Mendeley Desktop version 1.19.5 reference management program.

Table I. Search strategies and terms used.

\begin{tabular}{|c|c|}
\hline Database & Terms Of Research \\
\hline $\begin{array}{l}\text { PubMed } \\
\text { Filter used: Publication Date From } 2010 \text { to } 2020 .\end{array}$ & $\begin{array}{l}\text { ((Hypersensitivity OR Allergic Reaction OR Allergy } \\
\text { OR D elayed Hypersensitivity OR Immediate } \\
\text { Hypersensitivity OR F oreign-Body Reaction) AND } \\
\text { (Orthodontic Appliances OR D ental braces OR } \\
\text { Activator Appliances OR Removable Orthodontic } \\
\text { Appliances OR F ixed Appliance OR Retainer } \\
\text { Fixed OR Orthodontic Wires OR Orthodontic } \\
\text { Brackets)) }\end{array}$ \\
\hline $\begin{array}{l}\text { Embase } \\
\text { Filter used: Publications years (including): } 2010 \text { to } \\
2020 \text {. }\end{array}$ & $\begin{array}{l}\text { (Hypersensitivity OR Allergic Reaction OR Allergy } \\
\text { OR D elayed Hypersensitivity OR Immediate } \\
\text { Hypersensitivity) AND (Orthodontic Appliances OR } \\
\text { Dental braces OR Activator Appliances OR } \\
\text { Removable Orthodontic Appliances OR F ixed } \\
\text { Appliance OR Retainer Fixed OR O rthodontic } \\
\text { Wires OR Orthodontic Brackets) }\end{array}$ \\
\hline $\begin{array}{l}\text { ScienceDirect } \\
\text { Filters used: Publication Date From } 2010 \text { to 2020; } \\
\text { Research articles. }\end{array}$ & $\begin{array}{l}\text { (Hypersensitivity OR Alergic Reaction OR } \\
\text { Delayed Hypersensitivity OR Immediate } \\
\text { Hypersensitivity) AND (Orthodontic Appliances OR } \\
\text { Dental bracesOR Fixed Appliance OR Orthodontic } \\
\text { Wires OR Orthodontic Brackets) }\end{array}$ \\
\hline
\end{tabular}




\section{RESULTS}

In an initial search for terms, using the search strategies, 549 articles were found, 70 from the PubMed database, 126 from Embase and 353 from
ScienceDirect. Figure 1 shows the steps followed in this study, where after applying the inclusion criteria, only 04 articles were selected (Table II).

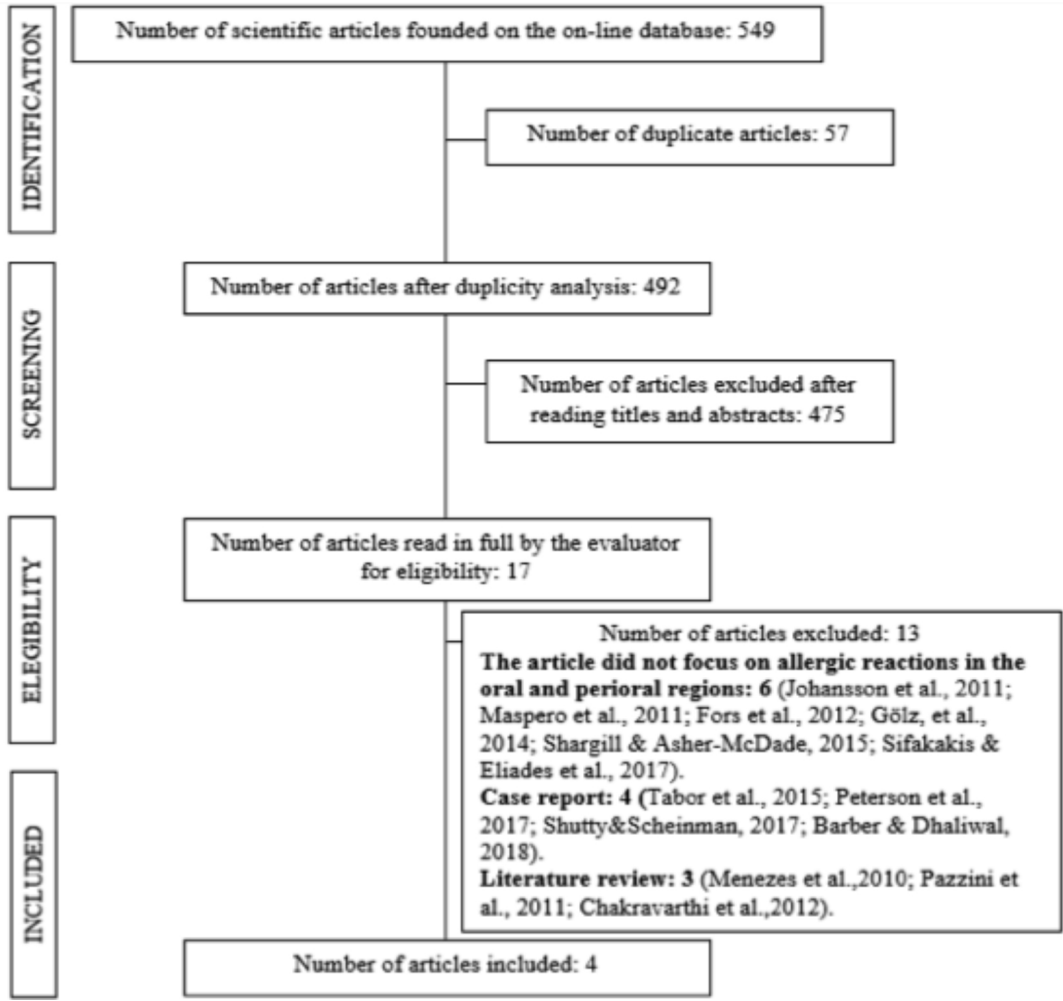

Fig. 1. Flowchart of selection of scientific articles.

Table II. Characterization of the articles selected in the review.

\begin{tabular}{|c|c|c|c|c|}
\hline Authors & Kind Of Study & $\begin{array}{l}\text { Sample } \\
\text { Size }\end{array}$ & $\begin{array}{l}\text { Area of allergic } \\
\text { reaction }\end{array}$ & $\begin{array}{l}\text { Orthodontic material } \\
\text { related to allergy }\end{array}$ \\
\hline $\begin{array}{l}\text { Pazzini et } \\
\text { al. (2012) }\end{array}$ & $\begin{array}{l}\text { Longitudina } \\
\text { I study }\end{array}$ & $\begin{array}{c}42 \\
\text { individuals }\end{array}$ & $\begin{array}{c}\text { Not explicit } \\
\text { (Erythema, } \\
\text { edema, papules } \\
\text { and blisters) }\end{array}$ & $\begin{array}{l}\text { A relationship was found } \\
\text { with the nickel of the } \\
\text { orthodontic appliance. }\end{array}$ \\
\hline $\begin{array}{l}\text { Amini et al. } \\
\quad(2011)\end{array}$ & $\begin{array}{l}\text { Longitudinal } \\
\text { study }\end{array}$ & $\begin{array}{l}72 \\
\text { samples of } \\
24 \text { patients }\end{array}$ & $\begin{array}{c}\text { Oral region } \\
\text { (Gingival } \\
\text { inflammation) }\end{array}$ & $\begin{array}{l}\text { A relationship was found } \\
\text { with the nickel and } \\
\text { chromium of the } \\
\text { orthodontic appliance } \\
\text { present in the gingival } \\
\text { fluid. }\end{array}$ \\
\hline $\begin{array}{l}\text { Pazzini et } \\
\text { al. }(2016 a)\end{array}$ & $\begin{array}{l}\text { Longitudinal } \\
\text { study }\end{array}$ & $\begin{array}{c}42 \\
\text { individuals }\end{array}$ & $\begin{array}{l}\text { Oral region } \\
\text { (Gingival } \\
\text { inflammation) }\end{array}$ & $\begin{array}{l}\text { A relationship was found } \\
\text { with the nickel of the } \\
\text { orthodontic appliance. }\end{array}$ \\
\hline $\begin{array}{l}\text { Pazzini et } \\
\text { al. }(2016 b)\end{array}$ & $\begin{array}{l}\text { Case-control } \\
\text { study }\end{array}$ & 96 patients & $\begin{array}{l}\text { Oral Region } \\
\text { (Periodontal } \\
\text { changes). }\end{array}$ & $\begin{array}{c}\text { A relationship with nickel } \\
\text { was found. }\end{array}$ \\
\hline
\end{tabular}




\section{DISCUSSION}

Orthodontic appliances, removable or fixed, are mostly metallic, polymeric and biocompatible ceramic structures. However, changes in their properties can result in the release of ions in biological fluids and in the oral mucosa, causing harmful actions to health, including allergic reactions. Adverse effects of some of these released substances, must be considered in the selection of the material and throughout the orthodontic treatment, in order to reduce possible undesirable implications (Sifakakis \& Eliades, 2017). In this context, it is extremely important to learn from the current literature, evidence that reports the relationship of the main substances present in materials used in orthodontics with the appearance of allergic reactions in tissues of the oral cavity and/or perioral region.

Preliminarily, due to the impossibility of access, there was difficulty in searching for studies in the PubMed, Embase and Science Direct databases, totaling 549 articles, which after the establishment of the criteria for the choice, aiming to limit the findings to the purpose of the review, those were selected. focused on allergic reactions that affect tissues of the oral cavity or perioral region arising from contact with orthodontic materials, which led to a number of only 4 articles that were based on such criteria. In fact, most of the selected articles date from the year 2016 and have, for the most part, a descriptive or longitudinal observational design.

Regarding the area of allergic reaction, 3 articles specified the inflamed portion, with the perioral surface not mentioned and the oral region having greater predominance among those studied. Thus, periodontal changes, such as gingival inflammation, have been described. Only, Pazzini et al. (2016a,b) did not explain the affected allergic region, addressing only the type of response of the organism in erythema, edema, papules and blisters.

In this context, it is known that hypersensitivity reactions to metals in dentistry are usually type IV, mediated by $T$ cells and monocytes/macrophages that can trigger harmful cascades with systemic or local manifestations (Menezes et al., 2009). In this scenario, among the materials most highlighted in the literature in relation to the emergence of such reactions, nickel, considerably, stands out.

In fact, nickel has a high allergen potential, which can cause discoloration of adjacent soft tissues, pain or allergic reactions (Quadras et al., 2019). Therefore, all selected articles related the presence of this substance to the appearance of allergic reactions in the oral cavity. Among these studies, Amini et al. (2016), associated, in addition to this substance, the chromium present in the device as an adjuvant in the gingival inflammatory process.

Thus, more research in this area becomes substantial in order to elucidate the association of oral reactions with materials used in orthodontics, so that the dentist and the patient can better understand the possible risks arising from the treatment, in view of that the hypersensitivity reaction, adversely affects the general health, and therefore, the individual's quality of life, as well as time, efficiency and satisfaction with the treatment (Maheshwari et al., 2015).

\section{CONCLUSION}

It is possible to conclude that reactions such as erythema, edema, papules, blisters and periodontal changes, for example gingival inflammation, are frequent manifestations of contact with orthodontic materials in patients allergic to nickel or, in some cases, chromium. Therefore, prior knowledge of the dentist is essential for the correct management and treatment of these adverse reactions.

ALENCAR, L. B. B.; SOUSA, S. C. A.; SILVA, I. L.; ARAÚJO, V. F.; OLIVEIRA, E. B.; FONSECA FILHO, D. T. A.; MACENA, M. C. B. \& FONSECA, F. R. A. Reacciones alérgicas en pacientes de ortodoncia: Una revisión. Int. J. Odontostomat., 15(1):132-136, 2021.

RESUMEN: Las reacciones alérgicas son respuestas inmunes del huésped a antígenos endógenos o exógenos, los cuales pueden provocar problemas locales y sistémicos. Entre los principales alérgenos se encuentran los materiales dentales utilizados en la ortodoncia, la cual se enfrenta a algunos desafíos respecto a la biocompatibilidad de los tejidos orales. Este estudio tuvo como objetivo analizar en la literatura que materiales utilizados en ortodoncia están relacionados con la aparición de reacciones alérgicas orales y periorales, así como investigar las manifestaciones más prevalentes. Se llevó a cabo una revisión con artículos publicados entre 2010 y 2020 en las bases de datos PubMed, Embase y ScienceDirect. Para ello, se utilizaron descriptores y si- 
nónimos de MeSH siguiendo dos campos semánticos: "Hipersensibilidad" en asociación con "Aparatos de Ortodoncia", la selección de estudios contó con las etapas de identificación, cribado, elegibilidad e inclusión. Ensayos clínicos aleatorizados, ensayos clínicos transversales o de cohortes; en la revisión se incluyeron pacientes con reacciones alérgicas que afectaron a la regiones oral o perioral debido al contacto con material de ortodoncia. De un total de 549 artículos sólo cuatro fueron seleccionados para el estudio. De acuerdo con lo que se analizó en la evidencia, las principales reacciones descritas fueron cambios periodontales, como inflamación gingival, eritema, edema, pápulas y ampollas . Además, en todos los artículos hubo una asociación con níquel y solamente en uno con cromo. Es posible inferir que las lesiones inflamatorias son manifestaciones frecuentes sobre el uso de níquel en pacientes de ortodoncia.

PALABRAS CLAVE: reacción alérgica, ortodoncia, materiales biomédicos y dentales.

\section{REFERENCES}

Amini, F.; Shariati, M.; Sobouti, F. \& Rakhshan, V. Effects of fixed orthodontic treatment on nickel and chromium levels in gingival crevicular fluid as a novel systemic biomarker of trace elements: A longitudinal study. Am. J. Orthod. Dentofacial Orthop., 149(5):666-72, 2016.

Andrade, E. D.; Costa, C. P. \& Ranali, J. Reações Alérgicas. In: Andrade, E. D. \& Ranali, J. Emergências Médicas em Odontologia. $2^{\mathrm{a}}$ ed. São Paulo, Artes Médicas, 2004.

Anusavice, K. J. Phillips - Materiais Dentários. $11^{\mathrm{a}}$ ed. St. Louis, Elsevier, 2005.

Barber, S. K. \& Dhaliwal, H. K. Allergy to acrylate in composite in an orthodontic patient: a case report. J. Orthod., 45(3):203-9, 2018.

Chakravarthi, S.; Padmanabhan, S. \& Chitharanjan, A. B. Allergy and orthodontics. J. Orthod. Sci., 1(4):83-7, 2012.

Fors, R.; Stenberg, B.; Stenlund, H. \& Person, M. Nickel allergy in relation to piercing and orthodontic appliances-a population study. Cont. Derm., 67(6):342-50, 2012.

Freire, W. P.; Fook, M. V.; Barbosa, E. F.; Araújo, C. D. S.; Barbosa, R. C. \& Pinheiro, Í. M. Biocompatibilidade dos Materiais Restauradores Odontológicos. In: Congresso Latino Americano de Órgãos Artificiais e Biomateriais, 2012.

Gaujac, C.; Oliveira, A. N.; Barreto, F. A. M.; Salgado, L. M.; Oliveira, M. S. \& Girão, R. S. Reações alérgicas medicamentosas no consultório odontológico. Ver. Odontol. UNICID, 21(3):268, 2009.

Gölz, L.; Bayer, S.; Keilig, L.; Jäger, A.; Stark, H.; Bourauel, C. et al. Possible implications of $\mathrm{Ni}$ (II) on oral IL-1 $\beta$-induced inflammatory processes. Dent. Mater., 30(12):1325-35, 2014.

Johansson, K.; Kerosuo, H.; Lammintausta, K. Nickel sensitization in orthodontically treated and non-treated female adolescents. Cont. Derm., 64(3):132-7, 2011.

Kumar V. \& Perkins, J. A. Robbins \& Cotran Patologia. Bases Patológicas das Doenças. $8^{\mathrm{a}}$ ed. Rio de Janeiro, Elsevier, 2010.

Maheshwari, S.; Verma, S. K. \& Dhiman, S. Metal Hypersensitivity in Orthodontic Patients. J. Dent. Mater. Technol., 4(2):111-4, 2015.

Maspero, C.; Galbiati, G.; Giannini, L. \& Farronato, G. Resine ortodontiche e fenomeni allergici. Mondo Ortod., 36(5):204-7, 2011.
Menezes, L. M.; Freitas, M. P. M. \& Gonçalves, T. S. Biocompatibilidade dos materiais em Ortodontia: mito ou realidade? Rev. Dent. Press Ortod. Ortop. Facial, 14(2):144-57, 2009.

Pazzini, C. A.; Marques, L. S.; Pereira, L. J.; Corrêa-Faria, P. \& Paiva, S. M. Allergic reactions and nickel-free braces: a systematic review. Braz. Oral Res., 25(1):85-90, 2011.

Pazzini, C. A.; Marques, L. S.; Ramos-Jorge, N. L.; Oliveira Júnior, G.; Pereira, L. J. \& Paiva, S. M. Longitudinal assessment of periodontal status in patients with nickel allergy treated with conventional and nickel-free braces. Angle Orthod., 82(4):6537, 2012.

Pazzini, C. A.; Pereira, L. J.; Marques, L. S.; Ramos-Jorge, J.; da Silva, T. A. \& Paiva, S. M. Nickel-free vs conventional braces for patients allergic to nickel: Gingival and blood parameters during and after treatment. Am. J. Orthod. Dentofacial Orthop., 150(6):1014-9, 2016a.

Pazzini, C. A.; Pereira, L. J.; Peconick, A. P.; Marques, L. S. \& Paiva, S. M. Nickel allergy: blood and periodontal evaluation after orthodontic treatment. Acta Odontol. Latinoam., 29(1):42-8, 2016b.

Peterson, M. R.; Wong, P. H.; Dickson, S. D.; Coop, C. A. Allergic stomatitis from orthodontic adhesives. Milit. Med., 182(3):18835, 2017.

Quadras, D. D.; Nayak, U. K.; Kumari, N. S.; Priyadarshini, H. R.; Gowda, S. \& Fernandes, B. In vivo study on the release of nickel, chromium, and zinc in saliva and serum from patients treated with fixed orthodontic appliances. Dent. Res. J. (Isfahan), 16(4):209-15, 2019

Shutty, B. G. \& Scheinman, P. L. Allergic contact mucositis caused by metal: a covertly located permanent dental retainer. Cont. Derm., 78(1):88-90, 2018.

Sifakakis, I. \& Eliades, T. Adverse reactions to orthodontic materials. Aust. Dent. J., 62 Suppl. 1:20-8, 2017.

Tabor, D.; Smith, V. M. \& Wilkinson, S. M. Chronic cheilitis caused by acrylates used as an adhesive for an orthodontic brace. Cont. Derm., 72(2):115-6, 2015.

Corresponding author:

Layla Beatriz Barroso de Alencar

Universidade Federal de Campina Grande

Centro de Saúde e Tecnologia Rural

Departamento de Odontologia

Avenida Universitária

Santa Cecília

ZIP CODE: 58708-110

Patos, Paraíba

BRAZIL

Email: laylabeatriz249@gmail.com 